\title{
The coexpression of EphB4 and EphrinB2 is associated with poor prognosis in HER2-positive breast cancer [Retraction]
}

Li X, Song C, Huang G, Sun S, Qiao J, Zhao J, Zhao Z, Li M. The coexpression of EphB4 and EphrinB2 is associated with poor prognosis in HER2-positive breast cancer. OncoTargets and Therapy. 2017;10:1735-1742.
OncoTargets and Therapy

\section{Publish your work in this journal}

OncoTargets and Therapy is an international, peer-reviewed, open access journal focusing on the pathological basis of all cancers, potential targets for therapy and treatment protocols employed to improve the management of cancer patients. The journal also focuses on the impact of management programs and new therapeutic agents and protocols on
The authors have advised us of concerns about the specificity of the primary antibody which have resulted in misleading and false results.

\section{Dovepress}

patient perspectives such as quality of life, adherence and satisfaction. The manuscript management system is completely online and includes a very quick and fair peer-review system, which is all easy to use. Visit http://www.dovepress.com/testimonials.php to read real quotes from published authors. 